\title{
What is respect?
}

\author{
Chaoyang Lin
}

National Taiwan Normal University, Taiwan

\begin{abstract}
Due to the globalization, people interact much more frequently which makes respect more important to promote the harmony than before. However, people from diverse cultures have different definitions to respect, so it is considerable to clarify the meaning of respect. As Homeric Hymns and the Book of songs have great influence on their own cultures for quite a long time, this research aims to find out what is respect in them. This research uses the hermeneutics and comparison methods to achieve this aim. The research finds respect is the foundation of people related to excellence and honor in Homeric Hymns, while that is related to the virtue in the Book of songs.
\end{abstract}

Keywords: respect, Homeric Hymns, the Book of songs 


\section{Preface}

When you passed by one place, you may hear "be respectful", however you feel strange, cause you think "I am respectful". That situation usually happens in our daily life. That happens much more frequently in the modern age. Though the covid-19 spreades globally greatly affects the normal life, people have been used to interact much more with those from different countries and cultures. Thus, distingushing the meaning of respect in different cultures matters.

Homeric Hymns and the Book of songs have great influence on their own cultures for quite a long time. Most westerners admit Greek culture is the homeland of their cultures. Jaeger (1939/ 1986: 38) thinks Homeric Hymns expresses the eternal knowledge of truth and destiny which is the creation of the heroic age. Even the Germanic epics, with all their nobility, cannot be compared with Iliad and Odyssey for depth and permanence. Jaeger (1939/ 1986: 39) points out Greek had a unique power of discerning and reproducing the elements in human life which are real and allembracing: for Homer, who stands on the threshold of Greek history, becomes the teacher of humanity. Homer passes over nothing without somehow honoring and glorying it. Even the man he didn't like, he called him a clear-voiced speaker. (Jaeger, 1939/ 1986: 42)

The book of songs is one of the six classics learned by students. 《Shidaxu 詩大 序》thinks the Book of songs is where the will in mind goes. The will expressed by the words forms the Book of songs. Emotions are moved in mind and expressed by the words. When words aren't enough to express emotions, people sigh; When sighs aren't enough to express emotions, people chant; When chants aren't enough to express emotions, people try to wave their hands and dance their feet. People's emotions are expressed by voices. Voices form some kind of articles (文) called music. The music of well-governed period is peaceful and happy showing the politics is harmonious; the music of troubled times is full of complain and angry telling the politics isn't harmonious. If the emperor wants to make the politics harmonious, move the heaven and earth, and touch the ghost and God, he should choose the Book of songs. The preemperors used the Book of songs to manage couples, form the filial piety and respect, urge the ethics, beautify teaching, and change customs.

Confucius said "In the Book of songs are three hundred pieces, but the design of them all may be embraced in one sentence -'Thinking purely"' (The Analects.Wei zheng 論語 . 為政) He also suggested his disciples to study the Book of songs : "My disciples, why not study the Book of songs? The Book of Songs can uplift you, can make you observant, can help you to get along with people, can help you to use your anger [in a 
proper way]. Applied near at hand, you can serve your father; applied at a distance, you can serve your ruler.” (The Analects. Yang Huo 論語 . 陽貨) Confucius thought “When you enter any state you can know what subjects (its people) have been taught. If they show themselves men who are mild and gentle, sincere, and good, they have been taught from the Book of songs.” (The Book of Rites. Jing Jie 禮記 . 經解)

From those comments to the Book of songs, it is believed the Book of songs has become an important textbook in Confucianism. The Confucianism is the mainstream of education supported by most emperors and massively affects Chinese and other countries which share the culture of Confucianism.

Finding out what is respect in them may explain why people argue they feel disrespected, and others feel innocence from different cultures. This research uses the hermeneutics and comparison methods to achieve this aim.

To begin with this research, it's necessary to know the backgrounds of Homeric Hymns and the Book of songs. Yang Shenkeng 楊深坑(1999 : 18) thinks historical research helps to understand special mental situations and the process of how the cognitive model of nations or regions forms. Thus, researching the historical background of Homeric Hymns and the Book of songs is important to explain why they form their "respect".

\section{The Backgrounds of Homeric Hymns and The Book of Songs}

Homeric Hymns and the Book of songs are the earliest collections of poems in the West and the East. They were formed in unique backgrounds and social cultures. Understanding the background of their times helps to comprehend the contents of them. The following discusses politics and war, society and economy, religion and education, family organization and family concepts. This part is mainly revised and translated from the author's paper(Lin Chaoyang 林昭陽 , 2019).

\subsection{Politics and War}

Homeric Hymns and the Book of songs show a clear contrast in political style and war. The description is as follows:

\subsubsection{The politics in Homeric Hymns belongs to the embryonic city-state politics, and the war is a small war that emphasizes bravery}

The time of Homeric Hymns is about ten to eight BC. It is generally called the Dark Age or the Age of Heroes. At this time, Greece is not a unified kingdom, but is composed of communities (共同體). Leaders of the communities are called Basileus. 
There is a large gap between Basileus and autocratic emperors. There is no bureaucracy and regular taxes to support the operation of $t$ communities. Basileus must negotiate with others and invite others to cooperate, which is regarded as the embryonic city-state politics.

The economic conditions of the Homeric era affect the economic status of Basileus. Basileus does not have a fixed tax. Even if there is some form of tribute system, it doesn't have a regular nature. It is only collected occasionally when Basileus has special merits or special needs. (Finley, 1991: 96) There is no war of conquest in Greece. Basileus can't obtain income from the outside. It can only rely on looted spoils and gifts or obtaining income from the land he possesses. Basileus also has some skills, for example, Odysseus can build ships, mow grass and plow which is very different from later monarchs. (晏紹祥 YanShaoxiang，2006 : 157-76)

The authority of Basileus to a large extent is personal power. Its existence and continuity are related to personal ability rather than the guarantee of systems. Although he is a supreme ruler of a community, his authority can't exist independently of the people (Andreev, 1979: 361-384). In addition to being restricted by political and economic status, his authority is also restricted by the presbytery (also known as the council) and the people's assembly. In the political system in Homeric Hymns, the Basileus, the council of nobles, and the people's assembly form a certain degree of three legs, Yan Shaoxiang 晏紹祥 (2006) believes that the three legs in Homeric era were based on unwritten habits. There is no clear division of the state's power. The three legs sometimes become two legs or one leg. Basileus and the council of nobles are more active, while the people's assembly is not dominant.

The goal of a war in Homeric Hymns is not to conquer and expand, but to simply rob. It is mostly carried out by private individuals. There is no regular army and unified military equipment. The military discipline is loose and lacks a unified command and pace. The war in Homeric Hymns emphasizes personal bravery, which reflects in the early stage of the city-state's formation, the organization and functions were not complete enough, and the control over individuals was very weak. This is the characteristic of the Greek city-state as a community of citizens. (Yan Shaoxiang 晏紹 祥，2006:252-256)

\subsubsection{In the era of the Book of songs, politics is a dictatorship of the monarch, while a war is an alien war that emphasizes loyalty}

After the Zhou Dynasty took over from the Shang Dynasty, it continued the political system of the Xia and Shang emperors. However, given that the Shang Dynasty ended of tyranny, the Zhou Dynasty overthrew the argument that the Shang Dynasty is 
sponsored by the God and advocated that the destiny (天命) should be obtained with the virtue matched with the heaven. Without the myth of God's will, Zhou people's political actions became cautious and thorough. The fengjianzhidu (封建制度) was used as the main political system, and the blood patriarchal system (宗法制度) complemented each other, making the Zhou king's rule more stable.

Just after the establishment of the Zhou Dynasty, in order to consolidate the new territory obtained from the Shang Dynasty, the Emperor Zhou directly took charge of the land of Wangji (王畿) around the capital and entrusted the clan and the meritorious statesman to the newly occupied land to assist the Emperor Zhou to manage the nation, and established the vassal state to defend the royal family, open up the frontiers and expand the Zhou Emperor's power. In addition to the division of lands, the Emperor Zhou also rewarded the clan and the meritorious statesman with titles. There are strict regulations on the ranks of titles, which are consolidated by strict etiquette and blood relationship. The titles include five levels: Duke (公), Marquis (侯), Uncle (伯), Zi (子), and Male (男). In addition to granting titles to them, they are also given symbols of conquering power such as clothing, bows, and arrows, etc. They must hold sacrificial activities with the Emperor Zhou and make an oath. The relationship between the emperor and the ministers is established through etiquette such as the order of the monarch and the oath of thanks from the courtiers and is maintained by the patriarchal and in-law relationship. (Liu Wei 劉煒， 2001 : 92-94) The Book of songs describes targets of wars as wars of aliens. Zhou people believed that the war was carried out as a last resort. For the aliens around, they should be inspired by culture first, so that they can be brought into the realm of civilization with the Zhou Dynasty. If it didn't succeed, Zhou people must fight a battle to survive. Zhou people are tired of fighting and must fight because of the belief in defending their homes and country, emphasizing loyalty to the country. The war in the Book of songs rarely has the opportunity for personal performance. Achilles is a personal hero in Homeric Hymns. This kind of personal performance is almost invisible in the Book of songs. (Li Shan 李山 , 1997)

Zhou people's "be cautious about wars" is expressed in the Book of songs as opposed to poor soldiers and military force. This is the most prominent expression of the Zhou people's "respect for morality" thought in handling tribal relations and war issues. (Wang Zhouming 王洲明 , 1997 : 49)

\subsection{Society and Economy}

Homeric Hymns and the Book of songs have similarities and differences in social and economic aspects. Here is the description as follows: 


\section{2-2-1The society in Homeric Hymns shows the privatization of land, social stratification, and been composed of communities. The economy in Homeric Hymns shows agriculture existed, and people bartered}

The society of the era reflected in Homeric Hymns can be explored in terms of land ownership, social stratification, and social organization. (Yan Shaoxiang 晏紹祥, $2006: 52$ )

Morgan (1887) thinks lands are the sign of the final establishment of land private ownership, Ridgeway (1885: 319-339) argues that the land in Homer's time was owned by the community. However, in Homeric Hymns, there is no obvious evidence to support the community possesses large tracts of well-cultivated land, and there was no organization that manages public lands. The possibility of temenos (territories) came from public lands is very small (Finley, 1981: 217-218, 225-230). The land in Homeric Hymns can be inherited from generation to generation, which shows that the land at that time can be privately owned. As far as the land is used to grow fruit trees, if the land is not privately owned, it seems there is no need to spend so much labor and effort. It can be true that in the Homeric era the land has been privatized.

The society of Homeric Hymns has been stratified, and the most important are the two classes of nobility and common people. The aristocracy is mainly composed of heroes, including the king, his cronies, and comrades-in-arms. The aristocracy is of noble origin and usually possesses a large amount of wealth. Aristocracies realize that they have higher social and economic statuses and consciously strengthen their special statuses. The common people in Homeric Hymns are called Demos. They are serious internally divided social aggregate. (Yan Shaoxiang 晏紹祥 , $2006: 66$ ) The upper class of the common people are wealthy and free people who have many lands and valleys. Those who have no lands become the beggars at the bottom of the common people. There are hired workers whose statuses are slightly higher than those of the beggars. These hired workers may be those who have lost their lands. (Andreev, 1988: 27-40) There are serious economic differences among the common people. It seems they are not enough to form an independent force. However, they can't be completely ignored. The common people have their own ideas. It isn't uncommon for them to attack the nobles. There are still slaves in Homer's society, mostly from prisoners of wars. Most of them are engaged in agriculture and domestic labor and some become masters' concubines.

The social organization of the Homeric era was in the early state stage, and various political institutions were relatively primitive. The city-state system was just sprouting, with limited authority, and lack in sufficient binding force on powerful families. (Yan 
Shaoxiang 晏紹祥，2006: 70-76, 117)

Glotz (1996: 7-12) thinks that the economy of Homer's era has transitioned from a family economy to an urban economy, Finley (1991: 55-73) believes that the economy of Homer's era is essentially a natural economy aimed to self-sufficiency. Although exchanging and handicrafts exist, it is mainly gift exchanging to meet family consumption. Profit is not the goal. Professional merchants and handicraftsmen are very few and despised by the upper class. The main social wealth in Homer's era was land, which was mainly used for grazing animals. However, whether animal husbandry accounted for the main proportion is not without doubt. From the epic, it seems that farming has certain importance and should even be dominant (Hans, 1992: 49-53). Finley (1991: 61- 66) points out that metal is difficult to obtain within the family or the community and must be obtained from the outside through gift exchanging.

\section{2-2-2The society in the Book of songs shows the well-field system, the social stratification, and been composed of families. The economy in the Book of songs shows agriculture is the primary productive activity and the currency is used in the initial stage of the business.}

The society in the Book of songs can be discussed from three dimensions: the wellfield system, social stratification and the patriarchal system.

The land system in XiZhou (西周) adopted the well-field system (井田制). Yang Kuan (1999) believes that the well-field system in XiZhou was a village community (村社) system. The well-field system did exist before the Spring and Autumn Period, existing public land, farmed by other eight households, for public use, and evenly distributed to each household's private land, at that time a man could get 100 acres, according to the system of a certain age. Nobles can have private lands. For example, the emperor and the nobles can seal the land to their subordinates, and the land can also be traded and used for compensation.

The society in the Book of songs has also been stratified, divided into three classes: nobles, common people, and slaves. The aristocracies are a hierarchy formed by patriarchal blood, including the emperor (天子), the princes (諸侯), the son of the princes (卿大夫), and the son of the prince's son (士). The common people are mainly farmers. Slaves, Yang Kuan (1999) believes that are captives mainly from wars could be exchanged with large quantities and low prices. Slaves were mainly engaged in agriculture, handicrafts, and reclamation of Mountains. The nobility, common people, and slaves are hereditary. Different identities have appropriate codes of conduct and cannot be overridden, thus maintaining harmony. Zhou people's ethical and moral values emphasize "harmony" rather than equality. It is the "harmony" under the strict 
hierarchy. (Wang Zhouming 王洲明 , 1997 : 49)

The patriarchal system is the blood inheritance law of the nobility, and it interacts with the fengjianzhidu. Zhou people developed a patriarchal system from blood and clan relationship, which strictly distinguished the order of sons born by the wife and concubines and the order of elders and youngers within the country and even the family. According to the patriarchal system, Emperor Zhou is the co-lord of the nation, and also the great prince of the same surname and dynasty officials. The princes and dynasty officials are the great patriarch of the same clan in the country. The emperor is the highest stratum among the nobles, the sons of the princes are the middle stratum among the aristocrats, and the sons of the prince's sons are the lowest stratum among the aristocrats. The following are numbers of common people and slaves, forming a pyramid-like social structure, and the hierarchical relationship of the entire society is strict. The restriction of the inferiority determines the superiority and inheritance, and then stabilize the social order. (Liu Wei 劉煒 , 2001 : 92-94)

The economy of the Zhou Dynasty entered the period of farming. The Zhou people knew how to use cattle, pick seeds, and use copper or iron farming tools. Food production was more advanced. (Sun Zuoyun 孫作雲, $1966: 75-90$ ) Due to the implementation of the well-field system, people almost had lands to cultivate, and agriculture was quite mature. People depended on agricultural production for their livelihoods, and had duties such as taxation, corvee, and contribution to the nobles. The handicrafts in XiZhou have a certain degree of maturity. The main handicraft industries are bronze casting, bronze mirrors, lacquer crafts, porcelain pottery, linen, silk weaving and embroidery crafts, bone making and clam making crafts. (Yang Kuan 楊寬 , 1999) Commercial activities are not particularly developed. Most of them are concentrated in the capital, mainly using true shells as coins (called good shells 貨貝), but also copper shells. (Liu Baocai 劉寶才，2002：125) Peng (朋) is one of the units of good shells used for rewards. The Shang and Zhou bronzes record that there are only four or more gifts of Peng, which shows that its value is quite high. (Ji Xusheng 季旭昇 , 1995 : 299-321 )

\subsection{Religion and Education}

In the era of Homeric Hymns, people worshipped humanized gods and ancestors. In the era of the Book of songs, people worshipped their ancestors, emphasizing on inheriting virtues of ancestors and matching the heaven with virtues. There were no words in the era of Homeric Hymns, and education was conducted in a broad sense. There were words in the era of the Book of Songs, and education was close to modern narrow education. The details are as follows: 


\subsubsection{In the era of Homeric Hymns, people worshipped humanized gods and ancestors, and conducted broad education}

During the Homeric epic period, the Greeks worshipped the gods of Olympus. These gods had similar nature and abilities to human beings. They would fight, quarrel, deceive, and be divided into different classes, each with different abilities and restrained each other. The Greeks also worshipped heroes, but with the spread of Homeric Hymns, ancestor worship also emerged at this time. (Lin Yuti 林玉体 , 1997; Yan Shaoxiang 晏紹祥，2006)

There are no words in the era of Homeric Hymns. It is estimated that the educational activities, the recipients, the instructors, and the purpose of education in this period are all with the original appearance of education. They are not affected by too many complicated factors. As the purpose of education is individual's mature and self-reliant in society, the learning content of the Greeks should be closely integrated with life at that time. There are new problems to be solved in life and those are what they need to learn. The instructor can be his father and brother, the person entrusted by the father and brother, peers, etc. Although there are no books, classrooms, and teachers, the education in Homer's era seems to be closer to those which emphasize the need to have a real situation, conform to the stage of physical and mental development, and cultivate personality by examples.

\subsubsection{In the era of the Book of Songs, people worshipped their ancestors, emphasizing matching the heaven with virtues, and education was close to modern narrow education.}

In the era of the Book of Songs, the Zhou emperor kept in mind the painful lessons of the demise of the Shang Dynasty and realized that the country cannot be lasted by relying solely on gods. Therefore, he advocated "respect for morality and protect the people" and emphasized the humanistic spirit (劉煒 Liu Wei , 2001 : 92-94). To the unknown power, Zhou people adopted a more humanistic and rational attitude, attached importance to the morality and cultivation of the person itself, and matched the heaven with virtues. It is believed the virtues of ancestors make great achievements, and descendants should follow them.

Zhou people's thought of "respecting virtues" is reflected in their views on the heaven. From "respecting the heaven", " praising to the heaven " to "blaming the heaven ", the Zhou people think the relationship between the heaven and men is embodied in people's virtues. The ruler with virtues can be blessed by the heaven, otherwise, the end would be like Sang Dynasty, so the emperor should be close to the wise and far away 
from the villain and rule the nation by virtues. (王洲明 Wang Zhouming , $1997: 48$ )

Education in Zhou Dynasty, according to the records of Da Dai Li (大戴禮), Book of Rites (禮記), Shang Shu (尚書), etc., Situ (司徒) was fully responsible for education administration, and Yuezheng (樂正) was responsible for enlightenment. The school system can be explained from Guoxue (國學, central school), local school (鄉學, township school), and talents selection. Guoxue is devided to Daxue (大學) and Xiaoxue (小學). Local schools are divided according to administrative districts. Settlements have Sishu (私塾, private schools). Villages have Xiangxiao (庠校, small schools). Townships have Xuxue (序學,sequence schools). Junguo (郡國，counties ) have Daxue (大學). The selection of talents started from the xiushi (秀士) in the township, then the XuanShi (選士), junshi (俊士), Zaoshi (造士) and finally reached the king of Zhou to be chosen to be officials. Situ, DaYuezheng(大樂正) and Sima (司 馬) are responsible for the selection. Excellent talents are rewarded. Those who are clumsy and rebellious will be taught again at different schools. If they are still rebellious, they will be sent to distant places. The school curriculum of the Zhou Dynasty emphasizes ritual and music, also morality and art. The curriculum of the local schools focuses on morality, behavior, and art with special emphasis on ritual and music. The curriculum of the Guoxue adds yi (儀) to morality, behavior, and art and also emphasizes ritual and music. Early childhood education is the family education received by Xizhou students before the age of nine. It is implemented in the family, starting from the children's speech, then daily behaviors, numbers and directions, classify men and women, comity (禮讓), and finally the calendar and counting. The ten-year-old boys learn from another teacher outside the home. Girls at home learn to sew and make clothes, cook, prepare for worshipping and provide a memorial ceremony, and how to become a good wife, etc., which helps them be adapt to the new life after marriages in the future ( National Institute of Translation and Compilation 國立編譯 館 , 1982 ) Aristocratic women will go to the clan's palace for pre-marital education before they get married, which is tantamount to pre-marital training. ( Lin Chaoyang 林昭陽，2003)

\subsection{Family organizations and family views}

The family in Homeric Hymns is a nuclear family, which is mainly managed by the male and emphasizes love. The family of the Book of songs is a large family, with the head of the household having the greatest power and attaches importance to the love of ethics.

2.4.1. The family in Homeric Hymns is a nuclear family, which is mainly managed 


\section{by the male and emphasizes love}

Andreev (1988: 83, 87) thinks the basic structure of Homeric society is the patrilineal family "oikos", dominated by men, Morgan (1887) points out that in Homeric society, women have no power that men must respect. In aristocratic families, in addition to family members formed by blood, there are still entourages and slaves. Men choose their spouses according to two families' matching. The husband is regarded as the owner and protector of wealth and has the right to speak. The requirements for the wife are loyalty, obedience, and housework. It is believed that if a wife lacks the custody of her husband, she may be tempted and bring destruction to the family. In the father-son relationship, the father is in the dominant position, and the father's property is inherited by the son, which is generally distributed equally. When the father is old, and the matured son becomes the core of the family. In the family concept, natural love is more important. (Yan Shaoxiang 晏紹祥 , $2006: 257-281$ )

\subsubsection{The family in the Book of songs is a large family, with the head of the household having the greatest power and attaches importance to the love of ethics.}

In the era of the Book of songs, agriculture was the main economic production. After the development of agriculture, more property was accumulated. In addition, productive activities depended on physically strong men, so marriages were mostly dominated by men. To protect property inheritance from outsiders, marriages enter exclusive marriages. That means a husband marries a single wife. However, the nobles still can have a concubine. The agricultural society requires more manpower, and the family is blessed with having many children and grandchildren. If a woman failed to bear children, the marriage may not last in serious cases.

In the big family, the head of household is mostly respected. The nobles have certain requirements for family members, and develop ethical norms based on their relationships, attaching great importance to the conformity of words and deeds to ethical norms. They express the love of their roles through appropriate words and deeds. Father and son, brothers and couples are the main ethics of the family, which extend to monarchs and his ministers and friends. Families are the core of the patriarchal system. Zhou people's ethical and moral concepts first extend from the harmony of family relations to the harmony of relations among members of the entire country. This is inseparable from the social characteristics of the patriarchal system. (Wang Zhouming 王洲明，1997：49) 


\section{Respect is the foundation of people related to excellence and honor in Homeric Hymns}

Jaeger (1986) says what Homer wants to express in Iliad and Odyssey is respect and honor, so exploring what is respect directly touches the main point of Homeric Hymns. Here will discuss the respect in Homeric Hymns from two aspects: respect is the foundation of people; respect is to be excellent and honorable.

\subsection{Respect is the foundation of people}

To Greek in Homeric Hymns, respect is the foundation of people. Here respect is close to dignity. Once people didn't been treated respectfully, people will be angry and struggle for respect.

Why is respect so important to be the basic of Greek in Homeric Hymn? As mentioned in the historical background, there is no nation and king having absolute power in Greece, Basileus must have many kinds of ability and invite other people to cooperate. That forms the respect for people, usually the aristocracy of noble origin and possessing a large amount of wealth. The city-state with limited authority lacks sufficient binding force on people. If Basileus wants to discuss public affairs, he should respect participants' decisions and invite them with good words. The communities are combined with the economic factor, so equality is important to keep cooperation and good relationship.

Respect (dignity) is so important, it presents people's position in the group. If one's dignity is violated, no matter how great the offender is, one will struggle for his dignity. Iliad is the poem of angry, focusing on Achilles' angry to Agamemnon. Agamemnon took away Achilles' symbol of honor without Achilles's consent. Achilles felt disrespected and refused to fight angrily. Because many Achaeans died, Agamemnon found he shouldn't take away Achilles' symbol of honor. He decided to give it back and give many presents for apologizing. However, Achilles was too angry to forgive Agamemnon. Many heroes urged him to accept. Phoenix urged Achilles to let his anger go and accept Agamemnon's gift: "Accept the gift! Achaeans will respect you like a god. If you don't get a gift and join the war of destruction, even if you stop the war, you will not be respected." (I9.603-605)

From Achilles, it shows respect (dignity) is the foundation of people. When people don't respect you and treat you equally, you should be angry to protect your dignity and right. And if you don't respect others, you should apologize with warm words and gifts. If someone offends you, and apologizes to you with gifts and sincerity, you should accept, or you won't be respected by people. 
But if one doesn't respect others and doesn't apologize, one may end with death. During Odysseus's wanderings, many suitors shamelessly proposed to his wife Penelope, consuming Odysseus' property endlessly, laughing at Telemachus, planing vicious plans against Telemachus, and regarded themselves as the male host. These rude and intemperate violations provoked Odysseus' anger. Odysseus eventually killed them all, leaving only the prophet and the poet chanting deeds to witness that justice is still standing in the world.

\subsection{Respect is to be excellent and honorable}

Dignity is the foundation of human existence in society and cannot be trampled on. However, having other conditions can make people more respectful. To heroes in Homeric Hymns, Arete is what they keep in mind. They eager to be excellent and outstanding, winning honor and praise for themselves.

What brings heroes honor and praise making them more respectful? The external decent and internal beauty, excellence, wealth surpasses everyone, and older heroes can win respect in Homeric Hymns.

Born to be tall and handsome, beautiful and sexy, coupled with cleaning and dressing to make oneself more decent, a decent appearance should match with nice inner. For example, tall and handsome people should be brave, good at fighting and eloquent. There is no lack of people only have good looks in Homeric Hymns. For example, Paris has a handsome appearance, but robbed Menelaus' wife, which brought destruction to Trojans. Another example is Nireus, the most handsome among all the Dananans reaching Ilios, second only to Achilles, but because of weakness, only a few people follow him (I 2.670-5).

Exercising the strengths and talents to the extreme is excellence (Arete), which can win the respect of others. For example, Achilles is brave and good at fighting, defending the home and country, and won the respect of the Achaeans. Odysseus is praised for being resourceful. The queen of Phaeacians is wise, noble and nice. She is respected for kindness and good at mediating disputes between men (O7.69-74).

Odysseus knows the importance of accumulating wealth far more than others (O19.282-6) and tries to gain much wealth. Telemachus exclaimed repeatedly when he saw Menelaus' tall mansion, felt that the palace was so beautiful as the brilliance of the sun and the bright moon (O4.44-6), and can't help but envy (O4.72-5).

Older heroes are respected not because of their age, but because of their accumulated rich experience and mature wisdom. Although Nestor is older among many heroes, he is still respected by Agamemnon, Achilles, Odysseus, etc. Because he is knowledgeable, honey-tongued, and speak fairly and reasonably (I1.48-53). He always 
inspires everyone, full of youthful vitality like young people (I4.313-36). Nestor said he fought bravely when he was young, and his physical strength declined when he was old. Currently, he wants to educate young people with words and persuasion (I4.31835, O3.360-3). Achilles held an amphora to Nestor at the Patroclus funeral contest (I23.621-3). Nestor happily accepted the gift and thanked Achilles for not showing any disrespect to him because he was not as good as before because of his age (I23.62638,643-50).

To Greek, being excellent is the way to earn honor for themselves.

\section{Respect is related to virtues in the Book of songs}

From the lesson of the Shang dynasty, Zhou emperor realized the relationship between the heaven and men is embodied in people's virtues. The ruler with virtues can be blessed by the heaven. Otherwise, the end would be like the Sang Dynasty. This background shows Zhou people paid attention to virtues and reflected in the Book of songs. Here will discuss respect in the Book of songs from two dimensions: respect is the virtue decides if you can stand in society and respect is to do what you should do as your roles.

\subsection{Respect is the virtue decides if you can stand in society}

In the Book of Songs, a virtuous person can be blessed by the heaven, stand in society, and be respected by people.

Because of Zhaogongshi's (召公奤) contribution to the Zhou Dynasty, Zhou people respected him and also cherished the Gantang tree where he once rested (The odes of shao and the south. Gantang 召南. 甘棠). After Wei (衛) was destroyed by Di (狄), Weiwengong (衛文公) moved to Chuqiu (楚丘) and re-established Wei (The odes of young. Dingzhifangzhong 府風．定之方中 ).He also contributed to Wei, and used Tao to transform the people so that the people disdained to run for sex (The odes of young. Didong 淜風. 蝃蝀). His courtiers are so kind (The odes of young. Ganmao 邝風. 干族).Poets sang to praise these sage emperors who make politics and culture nice. Weiwugong (衛武公) was good at articles, acceptting the suggestion, and defended himself with courtesy (The odes of wei. Qiao 衛風 . 淇奧). Qihuangong (齊桓公)saved Wei from destruction (The odes of young. Mugua 衛風．木瓜). Zheng wugong (鄭武公) has done a good job of Situ (The odes of zheng. Ziyi 鄭風. 緇衣) and praised by his people. Tang wugong (唐武公) merged with other countries and made outstanding contributions (The odes of tang. Wuyi 唐風. 無衣). Qin xianggong(秦襄公) was admired for his achievements in rituals, politics and military 
force (The odes of qin. Chelin, Situ, Xiaorong 秦風. 車鄰、駰驖、小戎).

The first ancestor of the Zhou Dynasty, Houji(后稷), experienced many difficulties in establishing the Zhou Dynasty. When the Zhou Dynasty suffered an accident, Zhougong(周公) stated the difficulties and reminded Zhou people to follow the spirit of their ancestors. (The odes of bin. July 國風．七月)

The king of Zhou Xuan (周宣王)was praised to be a sage emperor in the Book of Songs, because he conquered the South (Minor odes of the kingdom. Decade of nan you jiayu. Caiqi 小雅. 南有嘉魚之什. 采芑), and restored the system of gathering vassals to consolidate the royal family by declaring his authority (Minor odes of the kingdom. Decade of nan you jiayu. Chegong 小雅 . 南有嘉魚之什 . 車攻).He set an example for farming in the fields (Minor odes of the kingdom. Decade of nan you jiayu. Jiri 小雅. 南有嘉魚之什. 吉日) and made people live and work in peace and contentment (Minor odes of the kingdom. Decade of hongyan. Hongyan 小雅 . 鴻雁 之什 . 鴻雁).He was diligent in political affairs (Minor odes of the kingdom. Decade of hongyan. Courliao 小雅. 鴻雁之什. 庭燎) and builded a palace (Minor odes of the kingdom. Decade of hongyan. Sikan 小雅 . 鴻雁之什 . 斯干).He also restored the post of shepherd abolished by King li and the number of cattle and sheep (Minor odes of the kingdom. Decade of hongyan. Wuyang 小雅 . 鴻雁之什 . 無羊).

These kings are respected for their contributions to the country and society. Noble women are praised because of their beauty and noble origins. Wang Ji (王姬) looks like flowers of peach, plum andtangdi (唐棣). She is the grandson of King Ping (平王), the son of Qihou(齊侯)(The odes of shao and the south. Hebinongyi 召南. 何彼襛矣). Zhuang Jiang(莊姜) is the son of Qihou, the wife of Weihou (衛侯), the sister of Donggong (東宮), the aunt of Xinghou(邢侯), and the sister of Tangong's(譚公) wife. Her status is extremely noble. (The odes of wei. Shiren 衛風. 碩人)

As mentioned to interpersonal interaction, giving and returning can maintain a good relationship. Just like the poem says "There was presented to me a papaya, And I returned for it a beautiful Ju-gem ; Not as a return for it , But that our friendship might be lasting." (The odes of young. Mugua 衛風。木瓜)

It is believed in the Book of songs that if one doesn't respect others, then others don't respect him, too. The poem says "Look at a rat, it has its limbs; But a man shall be without any manner. If a man observes no manner, why does he not quickly die?"”(The odes of Yong. Xiang Shu 瘶風．相鼠) Qu Wanli (屈萬里) (1984) thinks this poem is to satire rude, and people can't get a foothold in society if they are rude. Another poem says "There are the branches of the sparrow-gourd; There is that lad, 
with the spike at his girdle. Though he carries a spike at his girdle, He does not know us. How easy and conceited is his manner, With the ends of his girdle hanging down as they do!”. (The odes of wei. Wanlan 衛風. 芄蘭) This poem is to satire Heigong (惠 公), because he is arrogant and rude (Shixu 詩序). Heigong became the emperor at young age, he is so arrogant of his talent. He enjoyed the prestige and didn't respect others (ZhengXuan's Jian 鄭玄嘎).

\subsection{Respect is to do what you should do as your roles}

Zhou people observe the heaven and politics, finding the heaven is always changing. Though Zhou people think the emperor is the son of the heaven and the heaven gives the emperor power to rule the nation. However, if the emperor doesn't do a good job, the emperor may lose his power and be replaced by a new king. But if he is so cautious about his virtues, then the heaven continues to bless his nation. Thus Zhou people are full of distress awareness (憂患意識). They are cautious about the disasters and do something to prevent them in advance.

The main political system, the fengjianzhidu complemented the blood patriarchal system make the Zhou king's rule stable. No matter in politics or in society, everyone has roles of corresponding virtues to keep harmony. Those virtues are taught at schools or in the family to let people know how to interact with different objects fittingly.

In the relationship between father and son, fathers should have the way of being fathers, caring and raising his son, and sons should be filial to his parents. (Lin Chaoyang 林昭陽 , 2019)

Couples is the beginning of relationships. Marriages are used to promote the union of men and women and reproduce offspring. Husbands are dominant, and wives should be tender and loyal, doing housework. (Lin Chaoyang 林昭陽 , 2019)

The emperor should possess nice inner qualities, brilliant appearance, diligence, and respect for the heaven, ancestors, and meritocracy. He should make people live and work in peace and contentment, too. Courtiers should have virtues of meritocracy, and respect the emperor. They should also devote to the affairs of the country with the emperor. (Lin Chaoyang 林昭陽，2019)

Brothers are the best assistants. They should always gather so as not to be separated by others. The Zhou dynasty divided the princes to secure the nation. Brothers 
have both blood and political relationships. Political relationships are unnatural and easy to be manipulated by interests. Awakening the natural blood relationship can ensure political stability. The elder brother loves the younger brother, and the younger brother respects the elder brother. (Lin Chaoyang 林昭陽 , 2019)

Friends learn from each other based on virtues and maintain long-term friendship. (Lin Chaoyang 林昭陽 , 2019)

There are hierarchical relationships among most of relations. The upper level like parent, emperor, elder brother, husband is expected to make decisions, take responsibility, and take care of the lower level. The lower level like children, people and ministers, younger brother, wife is expected to respect the upper level, be tender and humble.

\section{Conclusion}

Politics in Homeric era is close to city-state politics. Multiple powers are conducive to discussion and negotiation. It values equality, regarding respect (dignity) as the foundation of people and cannot be violated. The economic and social conditions at that time urges individuals to bring glory for individuals or groups with outstanding abilities. Heroic origins make them cherish their identities even more and strive to win glory for themselves and to be respected by others.

The politic power of the era in the Book of songs is concentrated in emperors. Emperors' power come from the destiny. Zhou emperors understand the impermanence of the destiny. They know they should respect the heaven and protect people. Futheremore, they should rule the nation with virtues and be cautious all times. They are also diligent in politics, loving people and courteous to wise men. Virtuous people who benefit people are respected, but rude persons cannot gain a foothold in society.

The political power structure is unified in Zhou Dynasty. The fengjianzhidu and the blood patriarchal system are used to strictly regulate the hierarchy to determine the transfer of power and the stability of the regime. It doesn't pay attention to equality but to harmony. Respect is everyone acts according to one's roles.

Due to the Backgrounds, respect (dignity) is the foundation of people and being excellent makes one more respected in Homeric Hymns. While in the Book of songs, respect is the virtue decides if you can stand in society and respect is to do what you should do as your roles.

As time goes by, some situations have changed. It is necessary to think about how to keep and renew the meaning of respect for the followers of Homeric Hymns and the Book of songs. 


\section{Bibliography}

Chinese reference

王洲明（1997）。論《詩經》的文化品格。文史哲，4，48-54。

Wan ZhouMing (1997). Dissgussion on the cultural characters in the Book of songs. Wenshizhe, 4, 4854 。

李山 ( 1997$)$ 詩經的文化精神。北京市：東方。

Li Shan (1997). The cultural spirit of the Book of songs. Beijing: East.

林玉体 ( 1997 )。西洋教育史。臺北市：文景。

Lin YuTi (1997). History of Western Education. Taipei: Wenjing.

林昭陽 $(2003$ 《詩經》國風貴族婚禮詩研究 - 以〈葛覃〉、〈桃天〉、〈菢有苦葉〉 、〈碩人〉為主要考據對象( 未出版之碩士論文〉國立臺灣師範大學國文系, 臺北市。

Lin Chaoyang (2003). A study on the nobles' Wedding poems of guofeng in the Book of songs-based on "Ge Tan", "Tao Yao", "Paoyou Kuye", "Shiren” (Unpublished master's thesis). Department of Chinese in National Taiwan Normal University, Taipei.

林昭陽 ( 2019 ) 荷馬史詩與詩經人格教育思想之比較 ( 未出版之博士論文 b 國 立臺灣師範大學教育系, 臺北市。

Lin Chaoyang (2019). Comparison on Personality Education Thinking in Homeric Hymns and the book of songs (Unpublished doctoral dissertation), Department of Education in National Taiwan Normal University, Taipei.

季旭昇 ( 1995 )。詩經古義新證。臺北市：文史哲。

Ji Xusheng (1995). New proof of ancient meaning of the Book of Songs. Taipei: Wenshizhe.

屈萬里 ( 1984 )。詩經詮䆁。臺北市：聯經。

Qu Wanli (1984). Interpretation of the Book of Songs. Taipei: Lianjing.

孫作雲 ( 1966 )。詩經與周代社會研究。北京市：中華書局。

Sun Zuoyun (1966). The Book of Songs and Social Studies in Zhou Dynasty. Beijing: Zhonghua Book Company.

晏紹祥 ( 2006 )。荷馬社會研究。上海市：上海三聯書店。

Yan Shaoxiang (2006). Studies in Homeric Society. Shanghai: Shanghai Sanlian Book Company.

國立編譯館 ( 1982 )。教育史。臺北市：正中。

National Institute of Translation and Compilation (1982). Education history. Taipei: Zhengzhong.

楊深坑 $(1999$ )。 知識形式與比較教育。臺北市：揚智文化。

Yang Shenkeng (1999). Knowledge forms and comparative education. Taipei: Yangzhi Culture.

楊寬（1999）。西周史。臺北市：臺灣印書館。

Yang Kuan (1999). History of the XiZhou Dynasty. Taipei: Taiwan Press.

劉煒 $(2001)$ 。中華文明傳真 2 商周 - 神權變革的一千年。上海市：上海辭書。 
Liu Wei (2001). Rechords of Chinese Civilization 2 Shang and Zhou Dynasties-a thousand years of theocratic revolution. Shanghai: Shanghai dictionary.

\section{劉寶才 $(2002)$ 先秦史。臺北市：五南。}

Liu Baocai (2002). History of the Pre-Qin Dynasty. Taipei: Wunan.

English reference

Andreev, J. V. (1979). Könige und Königsherrschaft in den Epen Homers〔Kings and kingship in the Epic Homers], kilo, 61, 361-384.

Andreev, J. V. (1988). Die homerische Gesellschaft〔The Homeric society〕, Kilos, 70, $5-85$.

Finley, M. I. (1981). Economy and society in ancient greece. London, UK: Chatto \& Windus.

Finley, M. I. (1991). The world of odysseus. London, UK: Penguin Books.

Glotz, G. (1996). Ancient greece at work: An economic history from the homeric period to the roman conquest. London, UK: Routledge.

Hans, V. W. (1992). Status warrior: war, violence and society in homer and history. Amsterdam, NED: J. C. Gieben Publisher.

Jaeger, W. (1986). Paideia: The ideals of greek culture (1 ${ }^{\text {st }}$ paperback ed.) (G. Highet, Trans.). New York, NY: Oxford University press. (Original work published1939)

Morgan, L. H. (1887). Ancient Society. Chicago, IL: Charles H Kerr and Company. Ridgeway, W. (1885). The homeric land system. The journal of hellenic studies, 6 , 319-339.

\section{Appendix 1 Classical Document Version}

詩經 (十三經注疏本 2 ) 毛亨傳. 鄭玄箋. 孔穎達疏。陸德明釋文 藝文印書館

The Book of Songs (Thirteen Classics Annotation and Commentary 2) MaoHeng's Chuan.

ZhengXuan's Jian. KongYingda's Shu. LuDeming's shiwen. Taipei: Art and Literature Press.

The Book of Songs. Retrieved from https://cti.lib.virginia.edu/shijing/ Anoshih.html

\section{禮記 (十三經注疏本 5 ) 鄭玄注. 孔穎達疏 藝文印書館}

The Book of Rites (Thirteen Classics Annotation and Commentary 5) ZhengXuan's Note. KongYingda's

Shu. Taipei: Art and Literature Press.

\section{左傳 (十三經注疏本 6 ) 左丘明傳。杜預注 . 孔穎達疏 藝文印書館}

ZuoZhuan (Thirteen Classics Annotation and Commentary 6) ZuoQiuming's Chuan. Duyu's Note.

KongYingda's Shu. Taipei: Art and Literature Press.

論語 $(十 三$ 經注疏本 8 ) 何晏注 . 邢昺疏 藝文印書館 


\section{IOM}

29-31 July, 2021

MUNICH, GERMANY

The Analects (Thirteen Classics Annotation and Commentary 6) HeYan's Note. Xingping's Shu. Taipei: Art and Literature Press.

The Analects of Confucius 論語 Translated by A. Charles Muller Retrieved from http://www.acmuller.net/con-dao/analects.html

Homer (10-8 B.C.). Iliad 1-12(A.T. Murray Trans., William F. Wyatt Rev.).

Cambridge, MA: Harvard University Press.

Homer (10-8 B.C.). Iliad 13-24 (A.T. Murray Trans., William F. Wyatt Rev.). Cambridge, MA: Harvard University Press.

Homer (10-8 B.C.). Odyssey 1-12 (A.T. Murray Trans., George E. Dimock Rev.). Cambridge, MA: Harvard University Press.

Homer (10-8 B.C.). Odyssey 13-24 (A.T. Murray Trans., George E. Dimock Rev.). Cambridge, MA: Harvard University Press.

Homer (10-8 B.C.). Iliad (Robert Fitzgerald Trans.). New York, NY: Oxford University Press.

Homer (10-8 B.C.). Odyssey (Anthony Verity Trans.). New York, NY: Oxford University Press. 